\title{
Appropriating spiritual help for traditional healing: why ancestors are needed ${ }^{1}$
}

\author{
Prof Jaco Beyers \\ Faculty of Theology and Religion \\ University of Pretoria, South Africa \\ Email: jaco.beyers@up.ac.za \\ Orcid id: https://orcid.org/0000-0001-5432-2898 \\ DOI: https://doi.org/10.46222/pharosjot.102.111
}

\begin{abstract}
This study investigates the use of traditional medicine by traditional healers in a South African context in the fight against Covid-19. Appropriating spiritual help in fighting the symptoms of the virus would be part of the treatment prescribed by traditional healers. This is not an evaluative study to judge whether traditional healing methods are valid or not. This is a descriptive exercise to show how traditional healers appropriate the help of the spiritual realm in the process of healing. Two different worldviews are discussed to indicate under which conditions the help of the spiritual realm is required in the healing process. The discussion of the porous and buffered worldviews provides insight into how people perceive their reality, and the influence of the spiritual realm in it. By describing how healing functions in an African (porous) worldview by adopting help from the spiritual realm, the importance of rituals as mediating actions, are emphasised. A porous worldview is not only found among African communities; several examples illustrate this. The conclusion drawn is that all illnesses and healing systems are culturally influenced, and one cannot be judged as being better or more efficacious than the other.
\end{abstract}

Keywords: healing; Covid-19; spirituality; worldview; traditional healer.

\section{Introduction}

During the 2020 international lockdown as a result of the Covid-19 virus, different measures were employed by governments in order to stem the spread of the virus. Worldwide, countries closed their borders, and households were confined to their primary residences. In many countries, all social interaction was prohibited as a precautionary measure. Health workers were deployed to assist in curbing the spread of the virus and assist the afflicted.

The Traditional Healers Association of the SADEC ${ }^{2}$ region reacted by imploring the South African government to consult and involve the traditional healers operating in rural areas to assist in fighting the spread of the virus. The chairperson of the Traditional Healers Association, Sylvester Hlathi, requested the Department of Health to enlist traditional healers in the fight against Covid-19. ${ }^{3}$ Although the Association did not claim to have a successful

\footnotetext{
1 This paper was presented as part of the programme at the Multi-disciplinary Socio-cultural Representations/Traditions of African Spirituality International Colloquium (Angels, Ancestors, Alchemy and the Arts of Africa), 29-31 October 2020, hosted by the University of Pretoria.

2 SADEC is the Southern African Development Community and includes 16 nations in the southern region of Africa. The goal of the organisation is to further social-economic and political cooperation among member states.

3 Interview (on SABS News) https://www.youtube.com/watch?v=JhrpukCzfMI\&feature=share) accessed 28/03/2020.
} 
treatment or access to a means of curing the virus, they did claim, according to Hlathi, that the healers could treat symptoms of the virus by means of traditional medicine. Hlathi's argument is that rural communities may still consult traditional healers during the time of illness owing to the lack of access to health treatment provided by the Department of Health in rural areas. Traditional healers still had to heed the warning to refrain from physical contact with patients. As when assisting patients with HIV, traditional healers claim to have access to traditional medicine that can alleviate the symptoms of the Covid-19 virus infection.

The request from traditional healers to be included in the fight against Covid-19 was reiterated by the chairman of the Council for Traditional Healers in the Durban region, Sazi Mhlongo. ${ }^{4}$ According to Mhlongo, traditional healers received no assistance in the form of medical equipment from the Department of Health to fight the spread of the virus. Apparently, clean water, which is essential in the healing treatment provided by traditional healers, was not provided to healers.

Traditional healers claim they can assist in the fight against the spread of the virus, but they have not been asked to assist by the Department of Health. They offered to help by means of providing treatment based on their knowledge of the medicinal value of plants and traditional healing treatments. The treatment traditional healers provide relies on the intervention of and assistance from the spiritual realm. One traditional healer, Nombulelo Doreen Ndiko from Carletonville, commented in an interview with Phumlani Langa from City Press (27 March 2020) that traditional healers can explain the meaning of the outbreak of the virus by "reading the bones". The spiritual means of healing is explained by a traditional healer in East London, Zandile Ntombela: "sangomas were traditional doctors led by ancestral spirits" (Palezweni 2020). Understanding the virus and healing it had to be appropriated from the spiritual realm. The restrictions on movement during the pandemic would thus affect traditional healers by preventing them from gathering herbs or consulting with spirits (Palezweni 2020).

This study investigates the way in which the spiritual realm is appropriated or enlisted in administering healing, as well as the metaphysics behind this endeavour. This is not an evaluative study to judge whether such methods are valid and true. This is rather a descriptive exercise to establish how traditional healers enlist the help of the spiritual realm in the process of healing.

Invoking spiritual help for healing is not a uniquely African phenomenon that only requires African explanations. Communities and cultures all over the world have different ways of perceiving reality and the place of humans within the greater scheme of things. A similar understanding of reality may even permeate a Western understanding. What becomes evident is that a particular worldview lies behind the appropriation of healing from the spiritual realm. Mokgobi (2014:27) attests to the way in which a worldview contributes to the way in which healing is perceived. We now turn to discussing the way in which worldviews are conducive to acquiring healing.

\section{Differing worldviews}

Peter Craffert (1997:1) makes it clear that illness and healing are determined by worldviews. Worldviews are in fact part of other systems (inter alia health care systems) that are constantly in dialogue with one another. Together with other systems, worldviews contribute to a cultural system (Craffert 1997:1). Worldviews are constructed and change, and bring about change owing to interaction with other social systems. The worldview becomes the framework determining humans' actions and behaviour. The way a human perceives illness and disease is therefore based on the cultural system. The result is that the same disease may be

\footnotetext{
${ }^{4}$ Interview (on SABC News) https://m.youtube.com/watch?v=tdGCjYgf1F0\&feature=share (accessed 28/03/2020.
} 
experienced differently by different individuals, depending on the cultural frame or worldview to which the individual subscribes (Craffert 1997:3).

What follows is a description of two possible worldviews. The Canadian philosopher, Charles Taylor, provides a helpful distinction between two ways in which worldviews are constructed.

\section{a. The porous self in an enchanted world}

For Charles Taylor (2007:34), the explanation of the existence of a perceived spiritual realm lies not in the differences between worldviews, but rather in an understanding of how the mind functions. For Taylor, if meaning is to be located within the human mind alone, it results in something different than when meaning is located 'exogenously' in objects outside of the human mind. Meaning outside the human mind results in an enchanted world where meanings are not located only in the human mind (Taylor 2007:32). This enchanted world is the world where spirits, demons, and powers, benevolent or malicious, exist (Taylor 2007:29). For the sake of our discussion, this is where we can add ancestors, angels, and such beings. These are beings, along with ghosts, referred to by Davies (2018:343-351) and Arnold and Walter (2018:352-361) as 'liminal beings' - beings in between worlds. This understanding of reality is taken to be the way things are.

Meanings not only reside in spiritual beings, but also in animate and inanimate objects, resulting in these objects ${ }^{5}$ carrying spiritual power, and existing independently and irrespective of human existence (Taylor 2007:32, 33). These meanings impact on human life from the outside, leading to a situation Taylor $(2007: 35,37)$ describes as living a life enforced by causality. This is what anthropologists traditionally referred to as animism. ${ }^{6}$ The enchanted world has no boundaries between these beings and powers and the world in which humans exist - no boundaries between personal agency and impersonal force, resulting in a world filled with numerous forces, affecting humans in many possible ways (Taylor 2007:33). Humans are thus liable to be affected by these entities that influence human existence owing to these porous boundaries.

For Taylor (2007:32, 35), these spirits, demons, and powers were (and are) implored to care, provide, protect, and also heal. The processes through which these effects are brought about is usually referred to as 'magic' (Taylor 2007:35). ${ }^{7}$ The 'porous self' is vulnerable to spirits, demons, and powers, which can cause fear (Taylor 2007:38).

There are thus no boundaries between subject and things, nor between minds and the world (Taylor 2007:35). The power is not solely within humans, but neither is it only located outside of humans. The power affects humans and penetrates human existence. This leads Taylor to think of the relationship as that of power residing in an interspace, a space between humans and things, or formulated differently, there is no clear boundary, but the boundary is porous (Taylor 2007:35). Human existence then opens up to things beyond ourselves, we become porous to outside power, whether good or evil (Taylor 2007:36).

Regarding a traditional way of understanding reality in Africa, Credo Mutwa (1998:560) attests to the division of reality into different spheres, with spirits residing in the upper or lower world to be summoned to the world of the living. The Most Ultimate God, to be distinguished from

\footnotetext{
${ }^{5}$ Compare in this regard the discussion of 'mana', 'taboo' and 'fetish' as concepts describing the way in which enchanted objects filled with power is seen. For a discussion on 'mana', compare Geo Widengren (1969:10). For a discussion on taboo, see Geo Widengren (1969:20) and Gerhardus van der Leeuw (1956:27), and for a discussion of fetish see Van der Leeuw (1956:19).

${ }^{6}$ Compare Edward Tylor (1878) Primitive Culture, defining animism as the belief that objects and beings other than humans have a soul.

7 Compare the way in which James Frazer (The Golden Bough) structures the evolutionistic development of religion, passing through the phases of magic, religion, and science.
} 
the lesser gods, resides in everything and everywhere, is the power behind everything, and is impossible to fathom or see (Mutwa 1998:561, 562). God created souls when he created himself. In African understanding, humans possess a soul as well as a 'self' (Ena) (Mutwa 1998:568). Although the Ena is not immortal, it grows over time into a human being, and can even exist for some time after the death of a body (Mutwa 1998:569). After the death of the body, the Ena returns to the invisible world known as the "land of Forever-Night" (Mutwa 1998:570) where the Enas continue to exist. Upon being forgotten by living relatives, the Ena of a deceased enters a state of non-being (Mutwa 1998:570). It is the purpose of the Enas to take the problems of the living to the gods and plead for help on behalf of the living (Mutwa 1998:569). It might appear as if people from Africa worship these spirits of the ancestors (the Enas), but as Mutwa (1998:570) points out, it is in fact the Enas that worship humans, as the Enas are dependent on humans to provide them with food through animal sacrifices. As gifts in return, the Enas implore the gods to bestow humans with wealth, luck, and protection (Mutwa 1998:570).

The porous self that exists in an enchanted world is not exclusive to African culture. Religions such as Buddhism, Christianity, Hinduism, Islam, and Judaism all subscribe to the belief in spiritual beings of some sort. This understanding of reality illustrates the porousness with which human existence is perceived. Humans are open to interventions from an invisible (spiritual) world where spirits, gods, beings, and powers reside.

\section{b. The buffered self in a disenchanted world}

On the same continuum at the opposite extremity to the enchanted world, stands the disenchanted world where the beings located in the enchanted world disappear, and the only minds that exist are those of humans (Taylor 2007:29). On this continuum ranging between the two extremities, a huge variation exists in how transcendence and immanence are experienced.

In a disenchanted world, no other mind besides the human mind exists. The existence of the spiritual beings is no longer experienced or anticipated. The disenchanted world requires a different existential condition (Taylor 2007:38). Humans living in the disenchanted world exist in a condition Taylor (2007:37) refers to as a 'buffered self' - humans are accordingly no longer porous in terms of being open towards the powers co-existing in this world. The buffered self is dislocated and at a distance from everything outside the human mind; true meaning is located and created within the human mind. There are clear boundaries between humans and the outside world. The boundary functions as a buffer preventing things outside of the human mind from affecting and influencing human existence (Taylor 2007:38). The buffered self is without fear, because it no longer stands vulnerable before spirits, demons, beings, and powers. Human existence is not deterministically subject to causality, but humans may participate in the outcome of their own existence (Taylor 2007:37).

Humans no longer feel vulnerable and exposed to outside powers shaping their existence (Taylor 2007:36). The disappearance of vulnerability leads to autonomy, self-control (Taylor 2007:39), and self-confidence. It is this self-reliance that the German philosopher, Friedrich Schleiermacher (1768-1834) warned against. According to Schleiermacher (1991:23), humans believe they are capable of satisfying their own spiritual needs by reading, rationalising, and contemplating this-worldly wisdom. Humans have become self-reliant with no more need for the spiritual reality. Humans have created a separate universum by filling their reality with self-created, earthly things. 
In order for religion to exist, a feeling of dependence on a metaphysical (spiritual) reality is required. ${ }^{8}$ For Schleiermacher $(1991: 48,52)$, human existence is existence in 'Anschauen des Universums' - a vision of the Ultimate, as well as viewing the Ultimate. Human existence is in the presence of the Ultimate. Human existence and the search for meaning are in the presence of, and under the constant gaze of the Ultimate.

The 'Anschauen des Universums' is what Peter Berger (1967:27-28) refers to as the 'Sacred Canopy': a reality created by humans and understood to contain meaning. Everyone is aware of the spiritual dimension that influences decisions and actions. Remove this canopy or frame of thinking, and the end result may be what is referred to as secularism or the disenchanted world.

Long before Taylor, the German sociologist, Max Weber (1864-1920), described how the world becomes disenchanted through a process of rationalisation. The world is emptied of gods and spiritual beings as scientific and rational explanations can account for phenomena previously ascribed to being the work of spiritual beings. This exercise in rationalism suppresses the belief in magic and causes the world to become disenchanted (Weber 1958:105; 1966:125). Through the process of rationalisation, the world is demystified; the mysterious in the world is explained rationally, leaving the world devoid of mystery and secrets. Weber (1966:125) called this the "world fleeing intellectualist religion". Through rationalism, there is no room left for the transcendental to operate in the immanent reality. Every mysterious event now has a logical, rational explanation.

For Taylor (2007:31), however, the disenchanted world does not negate the existence of gods or spirits, but this understanding situates belief in a realm where it is possible to doubt and question the existence of such beings. People are now allowed to question the existence and influence of powers exterior to the human mind.

A disengagement between humans and powers characterises existence in the disenchanted world (Taylor 2007:37). Did modern medicine - and by extension, science - bring about this disengagement, causing a disruption in equilibrium between humans' existence in the enchanted world? Humans out of touch (dislocated and disengaged) from the powers are alone, and need to be self-reliant. A balance can be restored when humans again connect to the enchanted world, and utilise powers and energy to heal. Healing is psycho-somatic: body and soul are mended.

It is this disengagement and disenchantment that may best describe the Western-infused model of science. Medicine, for example, is perceived to heal illness and disease. Medicine is the end result of rational processes of thought and experimentation, it is tested and has proven results of healing capabilities. Medicine in the enchanted world, however, may be the result of centuries of transmission of traditions on what cures and heals, also tested and proven, but it is not infused by rationalism, but by the connection to the enchanted world. Taylor (2007:39) attests to this by indicating that the enchanted world does not have the boundary that exists in the disenchanted world.

\section{Appropriating healing}

Now that the difference between the enchanted and disenchanted world has been explained, it becomes clear how, in some communities, it is (still) possible to expect healing to come from outside of humans through the intervention of a power.

\footnotetext{
${ }^{8}$ Schleiermacher, Taylor, Berger, and Weber represent a particular perspective on explaining religion in society. Although different from the perspective by Mutwa, it still provides insight on how the relation between humans and the spiritual realm can be presented.
} 
Taylor (2007:39) discusses appropriating healing in different scenarios of the enchanted and disenchanted realities. In the enchanted world, the absence of boundaries creates an openness between the spiritual and the material world. Objects imbued with power can be utilised to bring about a desired effect. Although the process may seem similar in the enchanted and the disenchanted worlds, it is not (Taylor 2007:39). Seeking medicine from a pharmacy (in the disenchanted world) may appear similar to seeking medicine from a traditional healer. The difference, however, is that in the enchanted world, the healing is not only for the body, but also for the mind (Taylor 2007:39). The mind needs healing, which is only possible through the intervention of powers and beings from outside the human mind. The boundaries in the disenchanted world make such interventions from outside unnecessary, ineffective, and unwanted. The medicine needs to enter the body and heal it from the inside through bio-chemical processes activated in the body; not enter the body and carry with it healing powers from the outside to the inside that instigate healing. Causality still plays a role, but the difference in the disenchanted world is the human participation in generating healing.

The way in which the powers and spirits are conjured and implored for assistance is by means of actions, words, and events, which brings about healing. Performing rituals are the activity between two distinct realities bringing about healing.

\section{Perspectives on how healing works for Africans subscribing to enchanted worldviews}

Moshabela (et al. 2016:84) differentiate between two paradigms that determine medical treatment: the 'biomedical paradigm' based on scientific (science of biology) knowledge and the 'healing paradigm' based on indigenous and religious knowledge. Some other authors agree with this differentiation of worldviews (compare Henriques 2013:60; De Andrade 2012:121). People subscribing to a particular worldview will consult with a healer who understands and functions within their particular worldview.

In many cases, dual worldviews exist, with people oscillating between the enchanted and disenchanted worlds. Africa is one continent, but not a homogenous world. There are in fact many 'Africas' on one continent, accounting for the many different ways of viewing reality. There are also many different types of traditional healers in Africa (Mokgodi 2014:28). Although African healers appropriate healing from the ancestors and spirits, traditional African healers (known as prophets) associated with Christianity make use of the help of angels in healing (Mokgodi 2014:29).

Historically in Africa, disease and illness tended to be considered the result of the ill-wishes of one person on another caused by witchcraft and magic (Mbiti 1969:165). According to Craffert (1997:2), in cultures with a low-developed concept of the self, by which he alludes to African cultures, disease and illness are often ascribed to malevolent social relations. Craffert (1997:2) refers to this as a personalistic medical system, where a disease is explained as the result of purposeful active intervention of an agent, whether human, non-human, or supernatural. The task of the traditional healer ${ }^{9}$ is to determine the cause of the disease, identify the perpetrator, and prescribe treatment that will bring about a remedy and prevent such evil from happening again.

In his explanations of African practices, Mbiti emphasised that healing is brought about by using objects imbued with power. He referred to objects such as plants, roots, leaves, fruit, bark, minerals, insects, bones, feathers, shells, and powders that are utilised in rituals (Mbiti 1969:163). De Andrade's (2012:122) explanation is that healing powers reside in the plants, and through the guidance of ancestral spirits, the cause of the disease can be identified. According to De Andrade (2012:122), traditional medicine can be smoked, inhaled, or drunk,

\footnotetext{
${ }^{9}$ Men or women can act as healers in society (Thorpe 1991:122). It would then be incorrect to refer to healers, as traditionally is the case, as 'medicine men.
} 
or used for washing or as ointment on the body. Most of the traditional medicine has not yet been researched scientifically, and it is still an ongoing process (compare Mothibe and Sibanda 2019:7). ${ }^{10}$

In his explanations, Mbiti insisted that knowledge of the natural world and knowledge about the nature of spirits and the living-dead (ancestors) and how to deal with them is necessary in order to effect healing (Mbiti 1969:164). The close connection Africans have with plants, according to Mutwa (1998:590), causes Africans to have knowledge of the medicinal value of plants (Mutwa 1998:658). This knowledge of medicinal plants is conveyed from the Enas of the deceased to those who have knowledge concerning how to communicate with the Enas.

Stephen Rutto (2020) reports from Kenya how a group of elders from the local region recently gathered for a healing ceremony. The elders cursed the Covid-19 pandemic in order to ward off the disease. The ritual was performed at a specific sacred location where local communities go to implore deities for assistance. Rutto describes the ritual performed in detail. The ancestors are the intercessors when pandemics like this strike. This is, however, not an isolated event. Rutto describes how communities in other regions of Kenya gathered for similar events to curse Covid-19. This serves as an example of how healing is appropriated in an enchanted world.

Mbiti (1969:165) and Thorpe (1991:123) stress that healing is physical and psychological. Mokgodi (2014:30) emphasises how Western healing tends to heed the biological (chemical) component of illness, while the traditional African healer focusses on the ancestors and witchcraft. It is clear that in many cases in Africa, disease is perceived as a religious matter requiring religious intervention ${ }^{11}$ (Mbiti 1969:165). The different rituals and ways of bringing about healing (physical and spiritual) are in fact irrelevant; the emphasis is rather on the social interaction between the healer and the afflicted, between humans and the spirits (Mbiti 1969:165). The duality in healing physically and psychologically is clarified in the process of healing. It may be made clear to, and even understood by the afflicted, that a parasite, bacteria, or virus may cause the disease, but the more important question is, 'why did I become sick?' (Thorpe 1991:123). The answer to this question relates to the ill-wishes of others and how the virus, bacteria, or parasite attacked a specific individual by mean of magic. Craffert (1997:2) states that although the naturalistic origin of the disease may be acknowledged, it is personalised, seeking causation in the supernatural realm. There must be a cause, rather than an explanation. ${ }^{12}$

Rituals become the actions that bring about healing. In a broader sense, rituals can be defined as repetitive, symbolic, meaningful, and communicative enactments of messages relating to the spiritual world (compare Grimes 2014:194). Not all human actions can be identified as rituals: only actions repeated with the same meaning and symbolic reference can be considered rituals. Rituals are thus a way for the participants to showcase the spiritual world in the physical world (Grimes 2014:202). It is clear that rituals do not only pertain to the physical, but also to the social and psychological (Segal 2005:375) and spiritual world (Grimes 2014:319). Rituals may have more meaning than meets the eye. People belonging to a particular cultural group understand the ritual and the symbolic meaning underlying it (Grimes

\footnotetext{
${ }^{10}$ Although the argument is applied here to traditional African medicine, much of the argument will also apply to western forms of 'untested medicine' such as vitamins and supplements which many people believe will improve their health. It does not fall within the scope of this study to address this matter further here.

${ }^{11}$ This is, however, a difficult matter in Africa as it is challenging to separate spheres of existence in a holistic understanding of reality, and to indicate when one is concerned with culture, religion, economics, or education.

${ }^{12}$ One should not think in terms of binaries by which westerners lead a buffered existence and Africans lead porous lives. There is evidence that westerners also move in and out of a porous existence..
} 
2014:319). Healing rituals should be understood as those actions that serve as a vehicle to transfer the healing power from the spiritual domain to this world.

In this sense, the rituals activate the metaxu that Plato discussed in his Symposium - the messenger between two worlds. The separation between the two domains of existence (spiritual and mundane) is bridged by what Plato refers to as the metaxu, a mediator separating and simultaneously connecting the spiritual and material worlds of the spirits, gods, and humans. Rituals enable the divide to be crossed. The mediating agency in this process belongs to the mediator, which, in Mbiti's (1970:224) Africa, is the traditional healer who is consulted in times of need and prescribes, and in some cases even performs, the required ritual. Through the ritual, the healing power is transferred from the spiritual realm to the mundane world.

In this regard, Taylor (2007:37) indicated how the enchanted world is governed by causality: exterior powers that influence human existence. In such a context, hospitals and medical assistance can cure bodies of diseases, but the traditional healer is necessary to bring pastoral comfort to the psyche of the afflicted, and assist in identifying the evil impetus of the one who wished the disease upon another (Mbiti 1969:166). While Mbiti explained this within an African context, one can imagine many others in which, if not the ancestors, then angels, or saints, or Jesus (through the mediation of a pastor or a priest, and not necessarily a traditional healer) are necessary to effect healing.

Mbiti (1969:166) insisted that the traditional healers are undeniably a necessity in African communities, providing comfort, reassurance, and hope that disease can be treated and healed. The way in which traditional healers adopt healing from the spiritual realm reflects the act of subscribing to the enchanted world, as explained by Taylor. It is, however, not only healing that requires acceding to the enchanted world. And, as has already been alluded to, this is not only an African phenomenon. To illustrate how the porous worldview functions in other communities outside of Africa, one example will be discussed.

During the period of the international Covid-19 lockdown, a news agency reported on a unique way in which a community tried to encourage the local inhabitants in a village to remain inside their houses in order to prevent the spread of the virus. A Reuters news reporter from Indonesia, Budi Perwanto (2020), reported how the local government in the village Kupeh on the island Java in Indonesia, was unable to convince local inhabitants to remain inside their houses during the lockdown. Officials consequently hired people to dress up as ghosts and hide in the town and patrol the streets at night. The decision was based on the assumption that "superstition" (read: the fear of .... for a community immersed in an enchanted worldview) will keep the people inside their houses. The ghosts, known locally as 'pocong' are believed to be the trapped souls of the dead who appear dressed in white cloaks.

The apparent reaction was that people were curious and wanted to see the ghosts. Only after some time did the ghosts have an effect. More and more people preferred staying at home rather than encountering the ghosts. This reflects an enchanted worldview where human existence is open (porous) to influence from the unseen world.

Returning to Africa: a similar example has been observed from Madagascar. Liesl LouwVaudran (7 May 2020) reports that, at a recent African Union meeting, the president of Madagascar, Andry Rajoelina, presented a herbal tea, which he claimed can cure Covid-19. The herbal tea is produced from a local Madagascan plant (artemisa), believed to contain medicinal properties. This might be true, but since it is still untested, it makes the claim spurious. Neither is the claim about the properties of the tea proof of spiritual powers that effect healing. Subsequently, the governments of Tanzania and Guinee-Bissau imported the herbal tea, and expectations regarding the mysterious working of the herbal tea were created. Presented as a wonder cure, it caused people to attach mysterious power to the plant. 


\section{Conclusion}

As indicated previously, the aim of this study was neither to discuss differences between healing systems, nor to evaluate the effectiveness of these systems. The aim was also not to theorise on the way in which worldviews influence and determine how healing is perceived, although this forms an important argument in this article. The main aim was to illustrate how healing and health care relate to the perceived existence of ancestors as spiritual beings employed for healing, among other functions.

It is therefore necessary to emphasise the following:

- The ways in which illness, disease, and healing are viewed is determined by the worldview

- It is unproductive to differentiate between which healing methods are good or bad, or more or less effective. No judgment of healing methods is intended here.

- Traditional healers are necessary in society. Their plea to be included in the government's fight against Covid-19 ought to be heard. The reason is that traditional healers heal holistically ${ }^{13}$, both body and mind; the physical body and the psyche are treated. Where the effect of a spell by an enemy is treated by healing the body physically, the fear of the one casting the spell and the ensuing evil, is treated psychologically.

- Traditional healers are custodians of culture and traditions, and contribute to the continuity of indigenous knowledge (compare Mokgodi 2014:30; Moshabela et al. 2016:86).

- All illness and healing systems are culturally influenced (Craffert 1997:2-3). A particular anthropological understanding determines the treatment of disease. A Western separation of body and mind, and separation from nature, requires a different approach to healing than a holistic understanding of the human (body, mind, and spirit) connected to the whole of the universe. ${ }^{14}$

The result is that no victor in the search for healing can be identified. In fact, this research emphasises that the more healing methods that are employed, the more beneficial it is to society. There will not be fewer consultations with traditional healers; in fact, according to De Andrade (2012:120), 70 to 80 per cent of people living in South Africa first consult traditional healers before consulting other health care practitioners (compare Setswe 1999:57). Mokgobi (2014:2) adds to this that 70 to 80 per cent of people who consult traditional healers in South Africa, do so for physiological, psychiatric, and spiritual needs. There is, therefore, clearly a significant demand for assistance from traditional healers. Even if the healing properties of traditional medicine are contested by biomedical health practitioners, a need for traditional healers will remain owing to the existence of a worldview that demands spiritual intervention.

\section{References}

Arnold, J. \& Walter, T. (20180. 'Angels', in Moreman, Christopher M. (Ed.), 2018, The Routledge Companion to Death and Dying. London: Routledge, 352-261.

Berger, P.L. (1967). The Sacred Canopy: Elements of a Sociological Theory of Religion. New York: Anchor Books.

Craffert, P.F. (1997). 'Opposing world-views: The border guards between traditional and biomedical health care practices.' South African Journal of Ethnology, 20(1), 1-8.

\footnotetext{
${ }^{13}$ In his critique of the claim to holistic healing, Craffert (1997:5) indicates that African healing claims to be holistic, but ascribes the origin of the disease to one source.

${ }^{14}$ Once again, it is important to note that not all westerners will always subscribe to a buffered existence.
} 
Davies, O. (2018). 'Ghosts', in Moreman, Christopher M. (Ed.), 2018, The Routledge Companion to Death and Dying. London: Routledge, 343-351.

De Andrade, V. (2012). " Traditional healers and modern doctors do not understand each other because they learn different things" South African traditional health practitioners' training with regards to hearing impairment,' in International Journal of Health Promotion and Education, 49(3), 120-127, DOI: 10.1080/14635240.2011.10708218.

Frazer, J. (1993). [1921], The Golden Bough: A Study in Magic and Religion. Hertfordshire: Wordsworth Reference.

Grimes, R. (2014). The Craft of Ritual Studies. Oxford: Oxford University Press.

Interview with Dr Sylvester Hlathi on SABS News

https://www.youtube.com/watch?v=JhrpukCzfMl\&feature=share (Accessed 28/03/2020)

Interview with Mr Sazi Mhlongo on SABC News

https://m.youtube.com/watch?v=tdGCjYgf1F0\&feature=share (Accessed 28/03/2020)

Langa, P.S. (2020). 'We spoke to a traditional healer about Covid-19', in City Press, 202003-27, www.city-press.news24.com. (Accessed 28 April 2020).

Louw-Vaudran, L. (2020). 'In tye van onsekerheid is die kwaksalwer koning,' Netwerk24, https://www.netwerk24.com/Stemme/Menings/in-tye-van-onsekerheid-is-die-kwaksalwerkoning-20200506 (accessed 8 May 2020).

Mbiti, J.S. (1969). African Religions and Philosophy. Second Edition. Oxford: Heinemann Publishers.

Mbiti, J.S. (1970). Concepts of God in Africa. London: SPCK.

Mokgobi, M.G. (2014). 'Understanding traditional African healing,' in African Journal of Physical Health Education, Recreation and Dance. September; 20 (Suppl 2), 24-34.

Mothibe, M.E. \& Sibanda, M. (2019). 'African Traditional Medicine: South African Perspective,' in Traditional and Complementary Medicine, viewed 18 May 2020, from DOI: http://dx.doi.org/10.5772/intechopen.83790

Moshabela, M.Z.T. \& Gaede, B. (2016). 'Bridging the Gap between biomedical and traditional health practitioners in South Africa,' in South African Health Review, 83-92.

Mutwa, C. (1998). Indaba, My Children: African Tribal history, Legends, Customs and Religious Beliefs. Edinburgh: Payback Pressh.

Palezweni, Y. (2020), 'Traditional healers not sure if they are essential service,' in DispatchLive, 18 April 2020. http://www.dispatchlive.co.za (Accessed 28 April 2020).

Purwanto, B. (2020). 'Ghosts' scare Indonesians indoors and away from coronavirus', https://www.reuters.com. Monday 13 Apr 2020. (Accessed 15 April 2020).

Rutto, S. (2020). 'Keiyo elders turn to culture, cast spell on Covid-19', in Standard Digital. https://www.standardmedia.co.ke/article/2001368169/keiyo-elders-turn-to-culture-cast-spellon-covid-19 (Accessed 21 April 2020).

Schleiermacher, F. (1991) [1899], Über die Religion: Reden an die Gebildeten unter ihren Verächtern. Gottingen: Vandenhoeck \& Ruprect.

Segal, R. (2005). Myth and ritual. In: The Routledge Companion to the Study of Religion, New York \& London: Routledge.

Setswe, G. (1999). 'The role of traditional healers and primary health care in South Africa,' in Health SA Gesondheid, 4(2), 56-60. 
Taylor, C. (2007). A Secular Age, Cambridge, Massachusetts: Belknap Press of Harvard University Press.

Thorpe, S.A. (1991). African Traditional Religions: An Introduction. Pretoria: University of Pretoria.

Tylor, E.B. (2016) [1878], Primitive Culture: Researches into the Development of Mythology, Philosophy, Religion, Language, Art and Custom. Translated by John Murray. New York:

Dover.

Van der Leeuw, G. (1956). Phänomenologie der Religion. Tübingen: JCB Mohr Siebeck..

Weber, M. (2003) (1958). The Protestant Ethic and the Spirit of Capitalism. Translated by Talcott Parsons. New York: Charles Scribner's Sons.

Weber, M. (1966). The Sociology of Religion. Translated by Ephraim Fischoff. London: Methuen.

Widengren, G. (1969). Religionsphänomenologie. Berlin: Walter de Gruyter. 